\title{
DIA INTERNACIONAL DA MULHER NO CAMPO BRASILEIRO: NOVAS FORMAS DE PROTESTO POLÍTICO E DE RESISTÊNCIA*
}

\author{
INTERNATIONAL WOMEN'S DAY IN THE BRAZILIAN COUNTRYSIDE: NEW \\ FORMS OF POLITICAL PROTEST AND RESISTANCE
}

Sônia Fátima Schwendler ${ }^{* *}$

\begin{abstract}
Resumo
Este artigo analisa as novas formas de protesto político e de resistência realizadas por mulheres camponesas brasileiras durante a celebração do Dia Internacional da Mulher. Desde 2006, as mulheres brasileiras da Via Campesina (movimento internacional de organizações camponesas) têm realizado ações radicais, a fim de reivindicar o dia 8 de março como o dia internacional de luta das mulheres trabalhadoras e questionar o modelo político, cultural e econômico de desenvolvimento. Seus esforços para quebrar o silêncio referente ao impacto social e ambiental da expansão do chamado "deserto verde", criado pela monocultura do eucalipto das grandes indústrias de papel do Brasil fornecem um caso notável de agência subversiva das mulheres. Baseado no documentário Rompendo o Silêncio, produzido pela Via Campesina para registrar a ação feita por 2.000 mulheres no Dia Internacional da Mulher em 2006, bem como entrevistas com as mulheres das organizações que contribuíram para o evento, este estudo argumenta que a ação radical das mulheres camponesas fornece novas percepções para a análise do feminismo na América Latina e no mundo. Há também a demonstração de que através das ações radicais e coletivas que desafiam as tradicionais formas de participação e os papéis de gênero, as mulheres camponesas tornaram-se uma das principais forças dentro do atual movimento camponês que reivindica o desenvolvimento de uma agricultura agroecológica e sustentável no Brasil.
\end{abstract}

Palavras-chave: mulheres, feminismo, Via Campesina, movimentos sociais, deserto verde, Brasil.

\begin{abstract}
This paper examines new forms of political protest and resistance carried out by Brazilian peasant women during the celebration of International Women's Day. Since 2006, the Brazilian women of La Via Campesina (International Peasant Movement) have taken radical action in order to reclaim 8 March as an international day of struggle by women workers and to question the political, cultural and economic model of development. Their efforts to break the silence about the social and environmental impact of the expanding 'green desert' created by the eucalyptus monoculture of the big paper companies in Brazil provides a remarkable case of women's subversive agency. Based on the documentary Rompendo o Silêncio (Breaking the Silence), produced by La Via Campesina to record the action taken by 2,000 women on International Women's Day in 2006, as well as interviews with women from the organisation who took part in

\footnotetext{
* Artigo publicado originalmente em inglês no Journal of History of Women in the Americas, 2014. http://dx.doi.org/10.14296/hwa.v2i0.2090. Traduzido por Camilla Gomes da Silva.

${ }^{* *}$ Pesquisadora Honorária da Universidade de Londres, Queen Mary College.
} 
that event, this study argues that peasant women's radical action provides new insights for the analysis of feminism in Latin America and worldwide. It also demonstrates that through their radical and collective actions, which challenge traditional forms of participation and gender roles, peasant women have become one of the major forces within the current movement campaigning for the development of an agro-ecological and sustainable agriculture in Brazil.

Keywords: women, feminism, La Via Campesina, social movements, green desert, Brazil.

\section{Introdução}

Este artigo analisa as novas formas de participação política e de resistência no campo brasileiro, focalizando as ações realizadas, desde 2006, pelas mulheres brasileiras da Via Campesina (movimento internacional de organizações camponesas) no Dia Internacional da Mulher, com o objetivo de reivindicar o dia 08 de março como um dia mundial de luta das mulheres trabalhadoras, utilizando a ocasião para criticar as consequências sociais, culturais, econômicos e ambientais do modelo hegemônico de desenvolvimento. A Via Campesina surgiu em 1992, tornando-se uma aliança internacional de camponeses, de organizações da agricultura familiar, de mulheres rurais e dos povos indígenas das Américas, Ásia, Europa e África. ${ }^{1} \mathrm{O}$ movimento se opõe ao modelo neoliberal que concebe a agricultura como um negócio de fins lucrativos, onde a agroindústria monopoliza os recursos produtivos. ${ }^{2} \mathrm{O}$ movimento propõe um modelo alternativo de agricultura e de vida no campo, baseado no paradigma da soberania alimentar, ${ }^{3}$ que "representa a construção de novos direitos e a transformação da sociedade como um todo". Isso inclui "a reforma agrária, com limites de tamanho máximo da área da fazenda e o controle equitativo dos recursos locais, tais como sementes, terra, água e florestas", bem como a ênfase na justiça social (equidade étnica, racial e de gênero). ${ }^{5}$ As mulheres camponesas brasileiras envolvidas na Via Campesina têm desempenhado um papel importante no âmbito local, nacional e internacional. Muitas delas já vinham participando de movimentos sociais na América Latina, em especial no Movimento dos Trabalhadores Rurais Sem Terra (MST), oficialmente formalizado em 1984, e no Movimento das Mulheres Camponesas (MMC), o qual tem estado na vanguarda das demandas do gênero feminino, desde meados dos anos 1980 . 
A luta pela democratização tem sido uma característica marcante na América Latina durante as últimas décadas, o que tem empoderado a sociedade civil e, contribuído para o surgimento de vários movimentos sociais. Jane S. Jaquette afirma que o envolvimento das mulheres nestas lutas sociais tem moldado a teoria feminista latino-americana dando-lhe um ponto de vista distinto para considerar as fronteiras entre o público e o privado, para abordar como a participação das mulheres na política poderá trazer mudanças sociais e negociar imagens e discursos políticos. ${ }^{6}$ Entretanto, embora a participação política das mulheres na América Latina tem sido amplamente estudada, ${ }^{7}$ a atuação política das mulheres camponesas tem sido largamente negligenciada na análise das principais correntes feministas, com algumas exceções. De acordo com Carmen Diana Deere e Magdalena León, o enfoque teórico das feministas internacionais e da América Latina têm sido em questões de reconhecimento ao invés de redistribuição. Deere e León afirmam que esse tipo de análise de gênero distancia o conceito de justiça das questões de classe, de economia política e redistribuição, redirecionando-o para a esfera cultural. As autoras enfatizam a necessidade de conectar as demandas materiais, em especial a questão da propriedade, com questões de reconhecimento, a fim de transformar as relações de gênero e acabar com a subordinação das mulheres aos homens. ${ }^{8}$

Não obstante os movimentos feministas nos EUA e na Europa tiveram alguma influência, o feminismo brasileiro foi moldado principalmente pela luta contra o regime militar (1964-1985). ${ }^{9}$ Céli Pinto argumenta que este feminismo, considerado um problema de petit bourgeois, ou seja, de pequeno-burguês, emergiu em um contexto de profunda desigualdade, com o desejo do restabelecimento da democracia. ${ }^{10}$ Como resultado, o movimento feminista brasileiro lutou pelos direitos universais do ser humano, incluindo os direitos das mulheres. Pinto ressalta que uma característica distinta do movimento feminista na década de 1980 era a participação massiva e organizada das mulheres durante o processo de elaboração e aprovação da Constituição Brasileira (1988). A partir da década de 1990, o feminismo mudou no Brasil, assim como em outras partes da América Latina, Europa e Estados Unidos. Dois importantes aspectos desta mudança incluem, em primeiro lugar, o crescente abismo entre os ideais feministas e os movimentos de base e, em segundo lugar, o processo de "ONGuisação", descrito por Alvarez. ${ }^{11}$ Estas mudanças tiveram um impacto enorme sobre o feminismo. Por um lado, as questões de gênero tornaram-se parte da agenda política do Estado, 
mas, por outro, as questões das mulheres foram enfrentadas através das ONGs (Organizações Não Governamentais), ao invés da ação dos movimentos sociais e da luta de massas de modo mais amplo.

Este estudo de caso da Via Campesina acrescenta outra faceta no tocante ao feminismo brasileiro: a organização e a posição de liderança das mulheres camponesas. Apesar da influência que o movimento feminista tem exercido sobre as organizações de mulheres rurais, a história feminista tem negligenciado as conquistas das mulheres rurais. Atualmente, os movimentos das mulheres camponesas não são apenas um dos movimentos mais enraizados, com uma complexa estrutura organizacional e uma capacidade de mobilização, mas declaram também que sua luta deriva de uma perspectiva feminista e de consciência de classe. ${ }^{12}$ Aqui, eu argumento que a análise da atuação subversiva das mulheres durante a celebração do dia Internacional da Mulher, pode-se oferecer novas percepções para a teorização do feminismo na América Latina e no mundo. Este artigo enfatiza as principais razões da ação radical das mulheres e como esta afeta a agenda feminista dentro do movimento social camponês. Minha análise é baseada no documentário Rompendo o Silêncio produzido pela La Via Campesina e em entrevistas com mulheres das organizações que participaram da notável ocupação da empresa de plantação de eucaliptos Aracruz Celulose no Dia Internacional da Mulher em 2006. ${ }^{13}$ Através da história oral, "o primeiro tipo de história”, esta pesquisa tem como objetivo capturar a dimensão subjetiva da vida e da experiência dos indivíduos expressa por um estreito vínculo com o seu meio histórico e sociocultural. ${ }^{14} \mathrm{Eu}$ entrevistei homens e mulheres de diferentes idades, etnias, participação política e experiência de trabalho que pertenciam ao Movimento dos Trabalhadores Rurais Sem Terra (MST) e ao Movimento das Mulheres Camponesas (MMC). Um dos principais temas que surgiu durante as entrevistas, particularmente no estado do Rio Grande do Sul, foi as novas formas de protesto das mulheres durante a celebração do Dia Internacional da Mulher. Para analisar esse fenômeno, este artigo considera as narrativas individuais das mulheres que participaram da ocupação da Aracruz Celulose (participantes e organizadoras) e suas interligações com outros entrevistados que mencionaram este tema.

\section{Atuação política das mulheres: novas formas de protesto político e de resistência}


A gênese dos movimentos de mulheres camponesas ocorreu durante a luta nacional pela democracia, empreendida na década de 1980, e a consolidação do movimento feminista e de mulheres no Brasil. ${ }^{15}$ As mulheres camponesas entraram na esfera política no processo de luta pela democracia, pelos direitos constitucionais e pela reforma agrária, em especial durante a reformulação da Constituição Federal, durante a década de $1980 .{ }^{16}$ Maria J. Carneiro argumenta que a participação política das mulheres do campo foi impulsionada por dois fatores principais: o movimento de resistência contra o aumento da expropriação de terras e exploração de trabalhadores rurais; e o surgimento de movimentos feministas e de mulheres, que contribuíram para o movimento de conscientização contra a ideologia opressiva de gênero. ${ }^{17}$ As mulheres sem terra e pequenas agricultoras entraram na atividade política por causa de seu status e de sua identidade como mulheres rurais da classe trabalhadora. Reconhecidas como iguais por organizadores que proferiam um discurso de igualdade de gênero, estas mulheres despertaram para um novo tipo de ação política que questionava seu status de subordinação de gênero dentro da igreja e dentro dos sindicatos de esquerda e dos movimentos sociais dos quais participavam. ${ }^{18}$ As principais demandas relacionadas ao gênero feminino, articuladas por essas mulheres rurais durante a década de 1980 foram a incorporação das mulheres em sindicatos rurais, o direito aos benefícios de seguridade social (incluindo licença-maternidade remunerada), aposentadoria e o seu reconhecimento como trabalhadoras rurais. ${ }^{19}$ Deere e León mostram que neste período "as garantias constitucionais que o movimento das mulheres conquistou no Brasil aparecem como singulares no contexto latino-americano", sendo este o primeiro país a ampliar os benefícios de seguridade social para as mulheres trabalhadoras rurais (trabalhadoras assalariadas, trabalhadoras temporárias e trabalhadoras familiares não remuneradas). ${ }^{20}$

O Movimento autônomo das Mulheres Trabalhadoras Rurais, o MMTR, que surgiu no sul e nordeste do Brasil em meados da década de 1980, esteve na vanguarda para as demandas das mulheres relacionadas ao gênero. No estado do Rio Grande do Sul, o MMTR foi formalmente criado em 1989 durante a Primeira Reunião Estadual de Mulheres Trabalhadoras Rurais. Foi incluída uma significativa representação regional e estipulado que o movimento seria autônomo. ${ }^{21}$ A criação do MMTR, no entanto, não foi o início do movimento. As mulheres começaram a se organizar em anos anteriores. 
Anita Brumer, por exemplo, demonstra que desde o final da década de 1970, o estado do Rio Grande do Sul foi o local de uma das maiores mobilizações das mulheres rurais no Brasil. Isto foi confirmado por uma das entrevistadas na história oral, S. C., uma das líderes do movimento, afirmou que "no fim de semana, nós costumávamos ir às comunidades para organizar as mulheres. Normalmente, realizávamos nossas reuniões após os trabalhos da igreja. Nós discutíamos os direitos das mulheres, incluindo o seu reconhecimento como trabalhadoras". ${ }^{22}$ Ela destacou também que antes da formação do MMTR, o movimento recebeu o nome de Organização das Mulheres da Roça, ou OMR. $^{23}$

Para aquelas mulheres no MMTR, a participação nas Comunidades Eclesiais de Base (CEBs), na Comissão Pastoral da Terra (CPT), nos sindicatos rurais e no MST havia servido tanto para desenvolver a sua consciência de gênero e de classe como para ampliar sua experiência de liderança. No entanto, muitas dessas organizações consideraram as demandas específicas de gênero como menos importantes do que as demandas econômicas e de classe. ${ }^{24}$ Como resultado, entre 1995 e 2004, as mulheres dos diversos movimentos sociais se reuniram para juntas criarem a Associação Nacional de Mulheres Trabalhadoras Rurais (ANMTR). Então, em 2004, os diversos movimentos autônomos de mulheres rurais, cada um com um nome distinto, se integraram sob uma única sigla: MMC (Movimento das Mulheres Camponesas). A organização identificouse como um movimento camponês, popular e feminista.

Significativamente, as mulheres também participaram desde o início da ocupação de terras realizada pelo Movimento dos Trabalhadores Rurais Sem Terra (MST). ${ }^{25}$ De acordo com João Pedro Stédile, o líder nacional do MST, três fatores foram cruciais na formação do Movimento dos Sem Terra. Além do impacto socioeconômico gerado pelas mudanças agrícolas, introduzidas pela ditadura militar na década de 1970 e, a simultânea luta em favor da democratização, havia um desafio ideológico à ideia de que os direitos à terra eram relacionados apenas aos direitos de propriedade privada, em vez de serem uma necessidade social, um ponto de vista defendido pela Comissão Pastoral da Terra (CPT), criada em 1975 com base nos princípios da Teologia da Libertação. ${ }^{26}$ 
Durante a fase de confronto da luta pela terra, as mulheres tornaram-se conscientes de sua posição como classe. Ao mesmo tempo, em decorrência de sua participação política, elas enfrentaram situações que contribuíram para a inclusão dos direitos das mulheres e a questão das desigualdades de gênero em sua agenda, visto que sua participação às colocou em contato com "novos padrões, ou geometrias de inclusão e de exclusão". ${ }^{27}$ Sua participação na luta pela terra e seu vínculo com os movimentos de mulheres e as perspectivas feministas levaram-nas a refletir sobre as ideologias e o habitus de gênero em que elas viviam. ${ }^{28}$ Como um produto da história, o habitus é "um sistema aberto de disposições que é constantemente submetido a experiências, e, portanto, constantemente afetado por estas de modo a reforçar ou modificar suas estruturas". ${ }^{29}$ De acordo com Maxine Molyneux, os interesses de gênero das mulheres podem ser desenvolvidos através de interesses práticos de gênero ("dados indutivamente e surgidos a partir das condições concretas do posicionamento das mulheres dentro da divisão sexual do trabalho") e interesses estratégicos de gênero (“derivados em primeira instância, dedutivamente, isto é, a partir da análise da subordinação das mulheres e da formulação de uma alternativa, um conjunto de arranjos mais satisfatórios do que os existentes"). ${ }^{30}$ A fim de negociar as relações de gênero e as estruturas de subordinação, as mulheres camponesas identificaram suas próprias necessidades práticas, transformando-as em interesses estratégicos. ${ }^{31}$

Três elementos foram chaves no apoio do MST à participação política das mulheres na luta pela terra. O primeiro foi o envolvimento das mulheres em diferentes níveis de organização interna do movimento, seguido pela formação de um Coletivo Nacional de Mulheres dentro do MST. ${ }^{32} \mathrm{O}$ terceiro elemento foi o compromisso com a paridade de gênero assumido pelo MST, que resultou na adoção da norma de que cada núcleo de base deveria ser coordenado por um homem e uma mulher. Em graus variados, esta medida tem sido adotada em outros níveis da estrutura interna do MST. Além disso, embora não fosse uma das principais demandas do movimento das mulheres do campo até 2000, as mulheres se envolveram na luta pela terra em função da demanda pela reforma agrária como forma de ampliar seu acesso à terra. ${ }^{33}$ Tais demandas para a distribuição da terra para as mulheres foram reivindicadas pela primeira vez em 1985 durante o acampamento da Annoni, a primeira grande ocupação massiva de terras realizada pelo MST, que envolveu 1.500 famílias. ${ }^{34}$ No Brasil, as mudanças constitucionais de 1988 introduziram a possibilidade da distribuição e 
titulação conjunta da terra para casais. No entanto, esta disposição tornou-se obrigatória apenas em $2003 .^{35}$

Foi durante a luta pela reforma agrária e pelos direitos de cidadania que as mulheres adquiriram o seu "capital político", um conceito desenvolvido por Else Vieira, que utilizou uma abordagem de gênero para os diversos tipos de capital concebidos por Bourdieu. ${ }^{36}$ As mulheres camponesas ampliaram sua consciência política e de gênero e suas habilidades de liderança através da sua participação na luta pela terra e na organização do movimento das mulheres rurais. ${ }^{37}$ Atuando nas esferas públicas, elas aprenderam a participar das discussões e negociações políticas e agrícolas, a coordenar reuniões e atividades em grupo, a dirigir os movimentos sociais dos quais participavam e lutar pelos direitos das mulheres no âmbito dos movimentos sociais, dos sindicatos, de partidos políticos e do Estado. Elas participavam de uma série de atividades distintas que desafiavam os pressupostos tradicionais sobre o lugar legítimo de homens e mulheres. Como resultado, muitas mulheres camponesas com pouca escolarização e sem capital político anterior, tornaram-se líderes chaves na luta pela reforma agrária e pelo direito das mulheres à terra.

A participação na luta pela terra e pelos direitos das mulheres não somente desafiou os papéis tradicionais de gênero, mas também proporcionou às mulheres experiência de liderança pública. De acordo com Sylvia Walby, tais transformações de gênero podem ser vistas como uma espiral; quanto maior a participação pública em uma esfera maior será a participação pública em outra. ${ }^{38}$ No entanto, as mudanças afetam as mulheres de modo diverso de acordo com a sua posição de classe, étnica e geracional, o seu papel nas lutas sociais e as diferentes formas de organização familiar. Leonilde Medeiros observa que a percepção de subordinação das mulheres não surge imediatamente com o envolvimento na luta, mas está relacionada com o processo de participação e a criação de condições que contribuam para a desnaturalização da dominação masculina e para o rearranjo dos papéis de gênero. ${ }^{39}$ Medeiros também destaca que a reorganização dos papéis de gênero é mais visível e permanente com as mulheres que assumem posições de liderança e tem acesso a análises teóricas. ${ }^{40}$ Anita Brumer e Gabriele dos Anjos enfatizam que quando as mulheres camponesas assumem funções permanentes na esfera pública, a sua posição de liderança é mediada pelo 
conhecimento técnico, organizacional, burocrático e político, em comparação com aquelas que só têm uma participação transitória na luta social. ${ }^{41}$

A politização das questões agrárias e de gênero, juntamente com a compreensão das estratégias da luta de classe e a prática da liderança, tem sido fundamental no desencadeamento dos protestos e das ocupações de terras, lideradas por mulheres camponesas. Renata Gonçalves argumenta que no Pontal do Paranapanema, região de São Paulo onde tem havido conflitos de terra, quando os homens eram presos, eram as mulheres que organizavam os protestos e as ocupações de terra. Fazendo isto, elas mostraram resistência, força e o desenvolvimento da prática de liderança. ${ }^{42}$ Além disso, durante o meu trabalho de campo no Brasil, em 2011, observei que as mulheres estavam liderando as lutas de massa do MST, especialmente no estado do Rio Grande do Sul. Além disso, as mulheres vinham lutando pelo direito à terra, à paridade de gênero na participação e representação, e a incorporação das questões de gênero nos debates das políticas agrícolas em nível local, nacional e internacional: "Elas estão realizando uma ação coletiva no campo da produção, que não é o espaço que as mulheres tradicionalmente costumam estar". 43

As mulheres rurais têm desempenhado um papel vital na produção agrícola e na organização comunitária. No entanto, na maioria dos países, as organizações camponesas e agrícolas ainda estão fortemente dominadas por homens. ${ }^{44} \mathrm{Com}$ a naturalização da hierárquica divisão sexual do trabalho, tornou-se socialmente aceito que só os homens decidem sobre a produção e a venda dos produtos, o que leva à dependência econômica das mulheres, seu confinamento à esfera doméstica e seu envolvimento em atividades consideradas femininas. ${ }^{45}$ Susie Jacobs mostra que, em muitas sociedades, o trabalho das mulheres na agricultura, na produção do artesanato e no processamento de sementes é essencial para a economia familiar. Geralmente, este trabalho é considerado "trabalho reprodutivo", menos valioso socialmente e dirigido pelo "chefe de família". Além disso, "as famílias chefiadas por mulheres não são consideradas propriamente famílias. Famílias chefiadas por mulheres foram, pelo menos até recentemente, muitas vezes, negligenciadas no processo de formulação das políticas". 46 
Considerando este contexto, a intervenção política das mulheres em questões de produção agrícola, incluindo a ocupação da fábrica da Aracruz Celulose em 8 de Março de 2006, pode ser considerada uma ação subversiva, tanto em termos de classe como de gênero. Na verdade, a decisão da ANMTR em 2000 de assumir o Dia Internacional da Mulher como um símbolo das mulheres camponesas contra o capital e o agronegócio, sem negar as suas necessidades específicas, tem sido considerada como um passo importante na direção da ampliação da igualdade de gênero e da conquista das demandas feministas. ${ }^{47}$ Desde então, as organizações rurais, através da Via Campesina, organizaram inúmeras ações similares e propuseram políticas públicas para o desenvolvimento de um modelo de agricultura camponesa. Como um movimento local / global, a Via Campesina tornou-se um dos movimentos sociais mais dinâmicos do mundo. Sua seção no Rio Grande do Sul foi formalmente criada durante o Fórum Social Mundial, realizado em Porto Alegre, em 2001.

\section{Rompendo o Silêncio através de ações subversivas}

Um exemplo notável de agência subversiva das mulheres foi sua ação de "romper o silêncio" sobre o impacto social e ambiental do crescimento do "deserto verde" gerado pela monocultura do eucalipto através das empresas de celulose instaladas no país mais extenso da América Latina. A produção de monocultura de eucalipto, que se tornou a forma predominante de desenvolvimento da indústria florestal, está causando um grande número de conflitos no mundo entre as empresas e as populações locais, e representa uma das questões mais controversas de sustentabilidade. ${ }^{48}$ De acordo com James Goodman e Ariel Salleh, a tensão social clássica entre centro e periferia é agora complementada por uma tensão ecológica entre a priorização da natureza para a produção de mercadorias e a priorização da natureza para a reprodução de um modo de vida. ${ }^{49}$

Em 8 de março de 2006 (Dia Internacional da Mulher), cerca de 2.000 mulheres camponesas da Via Campesina ocuparam a fazenda Barba Negra, a principal unidade de produção de mudas de eucalipto e pinus da Aracruz Celulose, no estado do Rio Grande do Sul, no município de Barra do Ribeiro, perto de Porto Alegre. Uma vez dentro da fazenda, as mulheres destruíram estufas e milhares de mudas de eucalipto. Suas ações geraram polêmica na sociedade brasileira, caracterizando uma luta contínua 
entre os camponeses e as comunidades indígenas de um lado e, de outro, o agronegócio. Este tipo de conflito é um fenômeno crescente no Sul Global. No entanto, o que é novo e notável sobre este tipo de demonstração é que este evento foi realizado apenas por mulheres. Em 2011, o estudo de Julien-François Gerber baseado em cinquenta e oito casos de conflito relacionados às plantações de árvores para a indústria nos países do Sul Global, demonstrou que a ocupação da fazenda da Aracruz Celulose no Rio Grande do Sul foi o único exemplo em que os manifestantes eram exclusivamente mulheres, embora o autor mostre que as mulheres têm se destacado em iniciar e / ou amparar a resistência em cerca de 10 por cento de todos os conflitos listados. ${ }^{50}$

Gerber também constatou que a principal causa da resistência "está relacionada com o controle corporativo sobre a terra, resultando em deslocamentos e no término do uso local dos ecossistemas, os quais são substituídos por monoculturas". 51 Igualmente, o principal objetivo do protesto das mulheres da Via Campesina era "para denunciar o impacto social e ambiental do crescente deserto verde criado pela monocultura do eucalipto". ${ }^{52}$ Esta posição é clara em seus depoimentos citados no documentário Rompendo o Silêncio, produzido pela Via Campesina, em 2006, a fim de explicar as principais razões para suas ações, tendo em vista que suas demandas não foram ouvidas na mídia oficial:

As mulheres da Via Campesina escolheram este lugar porque é uma das maiores ameaças e porque representa a face do agronegócio, especialmente em nosso estado. Há milhões de mudas, milhões de dólares de dinheiro público que estão sendo investidos em benefício desses empresários. Nós gostaríamos de entender como é que, se não há dinheiro suficiente para investir na agricultura camponesa, como tem tanto dinheiro para as grandes plantações de eucalipto, pinus, ou acácia, que são apenas para a produção de celulose? Gostaríamos de colocar na pauta de discussão do governo e da sociedade onde o dinheiro está sendo investido. Se ele gera alimentos ou materiais para exportação, ou para investimentos apenas. ${ }^{53}$

Nós entramos na empresa Aracruz Celulose, porque ela tem ocupado a nossa terra, especialmente no Rio Grande do Sul. Há mais de 250 mil hectares de terras com eucalipto. E nós sabemos que o eucalipto gera o deserto verde, a degradação do solo e a falta de água. Por isso ocupamos. Nós também ocupamos em solidariedade aos povos indígenas do Espírito Santo que tiveram suas terras desapropriadas pela empresa Aracruz Celulose. ${ }^{54}$ 
Várias agências, incluindo o Banco Mundial e a Organização das Nações Unidas para a Alimentação e Agricultura (FAO), têm promovido a expansão das plantações de madeira de rápido crescimento no Sul Global. Os governos concederam incentivos e subsídios para o setor privado, tais como subsídios de florestamento, investimentos em infraestrutura, impostos preferenciais e, mais recentemente, a Convenção de Mudanças Climáticas e o mercado emergencial de sequestro de carbono. ${ }^{55}$ Três outros fatores têm contribuído para o desenvolvimento de uma cadeia de produção de celulose no Sul Global: acesso a grandes quantidades de terras de baixo custo, força de trabalho barata e a ausência de legislação ambiental. ${ }^{56}$

Cerca de quarenta anos atrás, na época da "revolução verde", o Brasil se tornou o primeiro país em desenvolvimento a estabelecer plantações de madeiras de rápido crescimento em grande escala. ${ }^{57}$ A Aracruz Celulose SA foi criada em 1972, mas começou a operar sob o nome de Aracruz Florestal no estado do Espírito Santo, em 1967, durante a ditadura militar no Brasil (1964-1985). A partir de 1980, a empresa expandiu suas plantações de eucalipto para os estados da Bahia, Minas Gerais e Rio Grande do Sul. Com base em evidências do relatório social e ambiental da Aracruz de 2003, Alacir De' Nadai et al demonstra que a empresa oficialmente detém 375.000 hectares, dos quais 247.000 hectares foram utilizados para o plantio de eucalipto. Além disso, manteve o contrato de "avanço florestal" (plantio de eucalipto em propriedade de terceiros) ao longo de 58.000 hectares, envolvendo 2.593 agricultores. Sendo a maior produtora mundial de polpa alvejada de eucalipto (2,4 milhões de toneladas por ano), a empresa exporta 97 por cento da sua produção, principalmente para a Europa (38 por cento) e América do Norte (36 por cento). ${ }^{58}$

Em 2009, a Aracruz Celulose SA fundiu com a Votorantim Celulose e Papel SA (VPC), formando a Fibria. O logotipo da nova empresa é uma folha verde, uma nova "imagem;" que representa o compromisso da Fibria com o plantio de florestas, matéria-prima renovável e a preservação de florestas nativas. ${ }^{59}$ No entanto, este marketing de uma imagem positiva comercializado pela empresa contrasta com a história de resistência da comunidade e com as críticas de ONGs ambientalistas e movimentos sociais do campo, que criaram a Rede Alerta contra o Deserto Verde, em 1999. A Rede Alerta contra o Deserto Verde expressou diversas demandas, incluindo a implementação da reforma agrária, a restituição de terras às comunidades indígenas, 
quilombolas (residentes de um Quilombo, um assentamento no interior do Brasil fundado por pessoas de origem Africana, normalmente escravos fugitivos) e comunidades de pequenos agricultores, o apoio à produção local de alimentos e à conservação dos recursos naturais. ${ }^{60}$

Com base em depoimentos de centenas de índios, quilombolas e pequenos agricultores, De' Nadai et al relatara que a ocupação de 375.000 hectares de terras da Aracruz levou não só ao deslocamento de milhares de famílias do campo, incluindo índios Tupinikim e Guarani, quilombolas, pequenos agricultores, meeiros e trabalhadores rurais sem terra, mas também `a destruição de milhares de hectares de Mata Atlântica, que foram substituídas por eucaliptos. Plantações de árvores para a indústria, especialmente nas zonas costeiras, são propensas a causar um impacto negativo sobre os camponeses ou as populações indígenas que vivem nas proximidades, uma vez que erradicam a maioria dos bens e serviços ecológicos viabilizados pelas florestas. ${ }^{61}$ Geralmente, o efeito em rede sobre a biodiversidade é prejudicial porque as plantações de madeira de rápido crescimento fornecem um habitat menos adequado para a flora e fauna do que o dos ecossistemas que são substituídos, que podem ser danificados em função do uso de pesticidas. ${ }^{62}$

Entre 1968 e 1973, a empresa destruiu centenas de milhares de hectares de floresta nativa pertencentes às tribos Tupiniquim e Guarani no Espírito Santo, isolandoas dentro de seu próprio território. Anteriormente, havia mais de quarenta comunidades indígenas com mais de 30.000 hectares de terra, entretanto o Estado considerou as terras como "devolutas". ${ }^{63}$ Após a chegada da empresa, permaneceram apenas três comunidades e quarenta hectares. Havia cerca de 1.500 indígenas vivendo ali; hoje, existem apenas $680 .{ }^{64}$ Uma líder da comunidade Guarani aponta para a relação do impacto da empresa sobre a subsistência e o modo de vida dos povos indígenas: "Não nos faltava comida no passado como acontece hoje. Depois que as empresas plantaram eucalipto não há animais para caçar, não há floresta, não há nada para nos alimentar na floresta. Não há nenhuma cachoeira que ainda é boa porque eles envenenaram todas". ${ }^{6}$

Desde 1978, as comunidades indígenas têm se esforçado para recuperar suas terras. ${ }^{66}$ Em janeiro de 2006, aqueles que tinham reivindicado os 11.009 hectares de terra pertencentes tradicionalmente à tribo Tupiniquim e que ficaram sob o controle da 
Aracruz, foram violentamente expulsos pela polícia federal, que usou as máquinas da Aracruz para a destruição das casas indígenas:

Nós somos os proprietários de 18.000 hectares e do que as empresas roubaram de nós. E elas querem dizer que agora nós devemos parar a nossa luta. As mulheres estão aqui para isso. Porque houve um momento em que a empresa nos dizia os limites de onde poderíamos ir e hoje nós vamos dizer onde a empresa pode entrar e onde nós podemos ir. Aqui, existem 11.000 hectares; isto não é para eles, mas para as comunidades indígenas. ${ }^{67}$

Da mesma forma, a chegada da empresa levou ao deslocamento de muitos descendentes de africanos que haviam escapado da escravidão colonial (quilombolas). Em meados da década de 1970, antes da chegada da Aracruz, no norte do Espírito Santo, havia cerca de 12.000 famílias em um território de 256.000 hectares. Atualmente, apenas 1.300 famílias têm resistido, formando trinta e duas comunidades quilombolas. ${ }^{68}$

Octavio Ianni aponta que a história da terra na América Latina, evidente na história dos movimentos agrários, reflete diferentes modos do desenvolvimento intensivo e extensivo do capitalismo no campo. ${ }^{69}$ Neste contexto, a história da desapropriação de terras é apenas "um lado do processo de acumulação do capital. Isto é combinado com a subjugação do trabalho". ${ }^{70}$ Por exemplo, a "política agressiva de aculturação" implementada durante o governo militar obrigou as comunidades indígenas e quilombolas a entrarem numa relação contratual com a Aracruz Celulose para cultivarem eucalipto nas suas próprias terras. ${ }^{71}$ Este "out-grower scheme" consiste em uma nova estratégia global adotada pelas empresas do setor, para incorporar os agricultores no agronegócio do eucalipto e da celulose. ${ }^{72}$ Situação semelhante pode ser observada no estado do Rio Grande do Sul. Sergio Schneider descreve a evolução do cultivo de árvores, em que a acácia tornou-se uma cultura alternativa para os agricultores familiares, como um substituto para o cultivo agrícola diversificado. A fim de acumular capital, estas indústrias têm descentralizado suas unidades de produção para as áreas rurais, subcontratando a execução de determinadas etapas do processo de produção industrial. Isso não só transformou o processo de produção agrícola, mas também mudou a estrutura agrária. ${ }^{73} \mathrm{~A}$ indústria agrícola de celulose também seguiu o mesmo padrão. Uma líder comunitária assentada na Fazenda Annoni, no Rio Grande do Sul, apontou a tentativa feita pelas empresas que cultivam madeiras de rápido crescimento de subcontratar os agricultores familiares para cultivar eucalipto em suas 
propriedades. Ela destaca a influência das mulheres na decisão da comunidade para rejeitar a implementação deste projeto no assentamento. Ela diz que "as mulheres entendem quando não há comida suficiente em casa. Se nós cultivarmos eucalipto, na sequência só teremos madeira. O que é que vamos deixar para as novas gerações?"74

A expansão da monocultura de eucalipto no Rio Grande do Sul desde 2003 tem gerado controvérsia e resistência, liderada, muitas vezes, por mulheres. Segundo o relatório da Aracruz de 2006, a empresa possuía 104.000 hectares no estado: 66.000 designadas para o cultivo de plantações de árvores, 28.000 para a preservação da floresta e o restante para a instalação da fábrica. ${ }^{75}$ No entanto, os "contratos de avanço florestal" com outros agricultores não foram declarados. ${ }^{76} \mathrm{Se}$ as outras empresas, Votorantim e Stora Enso, estivessem incluídas, a área coberta por eucaliptos no estado teria sido de 300.000 hectares em 2006. Além disso, as empresas tem planejado expandir o cultivo de árvores para 1.000 .000 hectares até $2015 .{ }^{77}$ De acordo com Luiz Morelli, há elementos opostos: a agricultura familiar e a indústria da plantação de árvores, com concepções econômicas, ambientais e territoriais polarizadas. Por um lado, as empresas de plantação de árvores têm desenvolvido pesquisas a fim de promover uma expansão sustentável da monocultura de eucalipto, enfatizando o desenvolvimento econômico e social da região. Por outro lado, o Movimento dos Trabalhadores Rurais Sem Terra (MST) e, especialmente, a Via Campesina, defendem o desenvolvimento de uma economia familiar camponesa, baseada na redistribuição de terras e na preservação do bioma do Pampa. A Via Campesina argumenta que, enquanto uma empresa como a Aracruz gera apenas um emprego a cada 187 hectares plantados, lavouras de pequena escala produzem um emprego para cada nove hectares. ${ }^{78}$

As consequências da monocultura de eucalipto já são visíveis no Rio Grande do Sul. ${ }^{79}$ A monocultura teve um grande impacto no sul do Estado, em uma região chamada de "Metade Sul", que abriga o bioma chamado Pampa, um bioma único encontrado apenas nesta área; a introdução de espécies exóticas de árvores empobreceu o bioma nativo, o que levou à denominação de "Deserto Verde". ${ }^{80}$ A monocultura do eucalipto provocou uma queda na produção da água, empobreceu o solo e reduziu a biodiversidade. Apesar da controvérsia, o estudo de Gerber forneceu evidências de que a monocultura de eucalipto afeta as condições hidrológicas e de solo, uma vez que o eucalipto é um consumidor insaciável de água e sua taxa de crescimento depende dela. 
A qualidade da água de superfície também se deteriorou devido ao uso regular de pesticidas. $^{81}$

Além disso, Luiza Chomenko argumenta que a alteração do ecossistema tem efeito sobre a população da região, perturbando a sua identidade cultural. ${ }^{82}$ Isso pode ser visto claramente nos assentamentos localizados no sul do Rio Grande do Sul, que agora estão cercados por eucaliptos. De acordo com a E. S., assentada na Fazenda Annoni, que tem participado dos protestos contra a expansão da monocultura desde 2006, demostra que o cultivo de eucalipto em uma fazenda de 18.000 hectares, que foi previamente ocupada pelos trabalhadores sem terra e projetada para ser um assentamento, tem prejudicado a plantação de milho dos trabalhadores assentados. "Não colhe mais milho, os bichos comem tudo, de tanto periquito". ${ }^{83}$ Além disso, o cultivo de arroz nesta área foi substituído pela plantação de árvores. ${ }^{84}$ Leonardo Melgarejo observa que a Empresa Brasileira de Pesquisa Agropecuária (EMBRAPA), uma empresa estatal vinculada ao Ministério da Agricultura do Brasil, identificou os assentamentos como importantes para a produção de alimentos nos municípios em que estão localizados. ${ }^{85} \mathrm{O}$ autor argumenta que o cultivo de eucalipto pode ser um negócio rentável em curto prazo. No entanto, o impacto negativo na agricultura camponesa e o desenvolvimento territorial da "Metade Sul” seria irreparável.

Morelli afirma que a apropriação de terras por empresas industriais e a plantação de florestas de eucalipto levou à mudanças cíclicas, mas não à alteração da estrutura agrária, cujos elementos foram mantidos. Ele aponta para uma tendência de crescimento na região sul e em partes da Argentina e do Uruguai em que um grupo de empresas de celulose monopoliza fundiariamente certas áreas. ${ }^{86}$ Bernardo Mançano Fernandes argumenta que o aumento do poder territorial do capital significa perda, não só de terras, mas também de poder social e político do campesinato e vice-versa. Como o capital não reproduz o campesinato, na mesma medida em que o exclui, o campesinato reintegra-se na economia por meio da ocupação de terras. Através da cultura de resistência, ele foi criando e recriando uma estratégia política de luta pela terra, contra a expropriação e exploração dos meios de produção. ${ }^{87} \mathrm{O}$ estudo de Gerber identificou que a propriedade continua a ser a causa mais importante e imediata dos conflitos envolvendo a indústria da plantação de árvores. Outros fatores comumente relatados incluem concentração de poder, o deslocamento, a escassez de água e o 
desaparecimento dos recursos naturais. Gerber sublinha que esses conflitos são, de fato, as reações contra o processo da "acumulação capitalista por despossessão" ${ }^{88}$ Os camponeses ou os povos indígenas em protesto veem as plantações de madeira de rápido crescimento como "agentes exógenos invasores que minam seu acesso aos recursos naturais e aos serviços, seja terra, água ou recursos bióticos". Portanto, eles percebem a indústria de plantação de árvores como uma "ameaça a sua sobrevivência" e também a sua subsistência étnica. ${ }^{89}$

Considerando-se como descobridoras da agricultura, guardiãs históricas da vida e das sementes, e sendo as principais responsáveis pelo bem-estar de suas famílias, as mulheres camponesas trouxeram para o protesto o debate sobre a soberania alimentar. No âmbito internacional, as mulheres da Via Campesina alegaram que os povos da agricultura familiar tem o "direito de produzir o [seu] próprio alimento em [seu] próprio território". ${ }^{90}$ Elisabeth Witzel e Maria A. Silveira, participantes da da Via Campesina, evidenciam que "como sendo as que possuem maior responsabilidade na produção de alimentos, as mulheres são diretamente prejudicadas pela expansão da monocultura de eucalipto, principalmente quando elas são forçadas a sair do campo". Além disso, "os poucos empregos gerados pela indústria da celulose são geralmente dirigidos aos homens". 91 As atividades agrícolas das mulheres, apesar de serem consideradas, de modo geral, como uma ajuda adicional, têm desempenhado um papel importante na economia camponesa, garantindo a soberania alimentar e a biodiversidade. ${ }^{92}$ Uma análise econômica feminista tem chamado a atenção para esta contribuição vital. Estas análises também orientaram os protestos do Dia Internacional da Mulher. A demanda central na agenda da Via Campesina é o modelo alternativo de agricultura e de vida no campo, com base no paradigma da "soberania alimentar":

alimentação e agricultura são muito mais do que comércio e que, a partir de uma perspectiva ampla e inclusiva do desenvolvimento econômico local e nacional, a produção para os mercados locais e nacionais é mais importante do que a produção para a exportação, em termos do combate à pobreza e da fome; da preservação da vida rural, da economia e do meio ambiente; e da gestão dos recursos de modo sustentável. ${ }^{93}$

O modelo defendido pela Via Campesina inclui diversas demandas, como a adoção de mecanismos que promovam preços justos para os agricultores e consumidores, bem como "a reforma agrária, com limites de tamanho máximo de uma 
fazenda e com controle local equitativo sobre os recursos, tais como as sementes, a terra, a água, e as florestas". ${ }^{94}$ No entanto, como Annette Desmarais argumenta, o foco principal da soberania alimentar é a produção de alimentos e aqueles que realmente trabalham na terra. Por isso, "vai além da compreensão comum da segurança alimentar como garantia de que uma quantidade adequada de alimentos é produzida e disponibilizada para todos". ${ }^{95}$ Deve considerar os tipos de alimentos que são produzidos, onde e como eles são produzidos, e em qual escala.

As mulheres brasileiras da Via Campesina articularam essa perspectiva mais ampla, intrínseca ao modelo da soberania alimentar. Após a ocupação da Aracruz Celulose, elas levaram as mudas para a segunda Conferência Internacional da FAO sobre Reforma Agrária e Desenvolvimento Rural, realizada em Porto Alegre, capital do estado do Rio Grande do Sul. Lá, elas afirmaram que "a humanidade precisa cuidar do planeta, precisa de comida (arroz, feijão, e alimentos saudáveis). Ela não irá sobreviver de papel", chamando a atenção para o impacto negativo do agronegócio transnacional sobre as áreas rurais do Brasil. ${ }^{96}$ As mulheres tem uma posição particularmente importante em relação ao paradigma da soberania alimentar.

As mulheres da Via Campesina têm, de acordo com Desmarais, acrescentado também a questão da saúde humana como outra faceta do modelo de soberania alimentar, introduzindo a saúde como uma crítica à agricultura dependente de agrotóxicos, e defendido o desenvolvimento de uma agricultura ecológica e sustentável. ${ }^{97}$

Baseando-se em uma perspectiva feminista centrada em torno da luta pela vida, as mulheres camponesas têm defendido a produção de alimentos saudáveis, a preservação de sua sabedoria tradicional, a conservação do conhecimento medicinal e a proteção da biodiversidade, afirmando "como responsáveis pela reprodução da vida, nós lutamos para criar uma vida saudável para os nossos filhos". 98 Elas se opuseram fortemente contra o desenvolvimento de uma agricultura dependente de produtos químicos e de plantas geneticamente modificadas. Elas também denunciaram todas as formas de violência a que as mulheres rurais estão sujeitas: 
A vida das mulheres do campo é afetada pela violência capitalista e patriarcal mantendo-nos à margem e nas condições mais precárias. Sabemos que o sistema dominante traz muitas formas de exclusão e de práticas sexistas que são replicadas cotidianamente em nossas vidas, em nossas relações pessoais e nas nossas relações políticas, quando o nosso conhecimento, nosso trabalho e nossa contribuição econômica são desvalorizados ou negados. O modelo capitalista patriarcal anula a possibilidade de reconhecimento do trabalho feminino $\mathrm{e}$ as contribuições das mulheres rurais, tais como a conservação e a recriação dos nossos ecossistemas, nossa biodiversidade, nossos sistemas de saúde e a transmissão do conhecimento agrícola. ${ }^{99}$

Ao fazer isso, elas acrescentaram ao debate da soberania alimentar as questões da igualdade de gênero, dos direitos das mulheres e do empoderamento, adicionando uma perspectiva feminista à consciência de classe que requer transformações estruturais na sociedade.

\section{0 impacto e os resultados das ações radicais das mulheres}

Com o "rompimento do silêncio" no Dia Internacional da Mulher e, durante outras manifestações semelhantes, as mulheres da Via Campesina em todas as regiões do país têm ampliado tanto a sua agência política, assim como sua visibilidade. J. S., que já participou de mais de um protesto liderado pelas mulheres contra as empresas de eucalipto, aponta que quando as mulheres foram no âmago do capital para criticar os efeitos negativos do plantio de eucaliptos no meio ambiente e nas vidas humanas, os debates sobre esta questão já estavam ocorrendo; o que era novo era o protesto liderado somente por mulheres. ${ }^{100}$ Estes atos subversivos têm fortalecido o papel político das mulheres na sociedade, embora as tenha tornado vítimas da repressão política e da perseguição legal. As ações das mulheres se tornaram parte da criminalização dos movimentos sociais no Brasil, um processo amparado por uma aliança entre o sistema legislativo e os meios de comunicação de massa. ${ }^{101}$

Cristina Zanella Rodrigues analisou os discursos utilizados na cobertura da mídia sobre o caso Aracruz. Ela demonstra que, através do uso de uma linguagem tendenciosa e de imagens seletivas, as reportagens marginalizaram as demandas políticas e ambientalistas do protesto das mulheres e focaram apenas nos danos causados à Aracruz Celulose. ${ }^{102}$ Igualmente, Miqueline De Faveri mostrou que apenas três dos dezenove artigos publicados pelo Correio do Povo incluíam o ponto de vista da 
Via Campesina. Da mesma forma, nos dez dias após o evento, apenas dois intelectuais foram incluídos na análise e ambos foram contra a manifestação. ${ }^{103}$ Usando uma perspectiva claramente capitalista que defende a propriedade privada, a mídia retratou a empresa como a vítima e condenou as ações das mulheres através do uso de adjetivos, como "vandalismo", "depredação", "invasão" e "destruição". Por exemplo, a fúria das mulheres camponesas foi contrastada com o "bom senso" de Isabel Gonçalves, pesquisadora da Aracruz, que afirmou que muitos anos de pesquisa tinham sido destruídos. $^{104}$

A postura assumida pela mídia deu voz à empresa e ignorou as motivações políticas que levaram as mulheres a realizar uma ação tão radical. ${ }^{105}$ Os políticos adotaram uma abordagem similar. Por exemplo, o governador em exercício do Rio Grande do Sul, Antônio Hohlfeldt, descreveu o protesto das mulheres como "provocação e banditismo" enquanto que o ministro do Desenvolvimento Agrário, Miguel Rosseto, também condenou o evento, dizendo que "este tipo de ação violenta não contribui para o projeto de reforma agrária". ${ }^{106}$ Ao assumirem-se como representantes da sociedade em geral, tanto os meios de comunicação, quanto os governos apresentaram um discurso "quase consensual" sobre as ações das mulheres, sem analisarem o impacto ambiental da monocultura do eucalipto. ${ }^{107}$ Como J. S., líder regional do MST, enfatizou durante uma das minhas entrevistas: "a mídia mostrou apenas os danos causados pela Via Campesina, mas os danos que a empresa está causando ao nosso solo, à nossa nação não estavam em questão". ${ }^{108}$ Como resposta, a Via Campesina publicou um livro introdutório no qual refutou a acusação da mídia de que as mulheres camponesas haviam destruído o laboratório de genética da Aracruz e vinte anos de pesquisa, mostrando ser esta uma falácia já que o laboratório de genética encontra-se em Aracruz, no Espírito Santo. ${ }^{109}$ A Via Campesina argumenta que, inverdades como estas são simbólicas da criminalização do movimento social camponês.

Tanto as reportagens da mídia sobre a manifestação, assim como as respostas políticas também tentaram ocultar e negar a ação das mulheres, enfatizando a necessidade de descobrir "quem está por trás da ação das mulheres". Por exemplo, a mídia tentou insinuar que as mulheres tinham sido enganadas e que elas agiram a mando dos homens, particularmente sob a liderança do Movimento dos Trabalhadores 
Rurais Sem Terra. ${ }^{110}$ Os meios de comunicação, um espaço privilegiado, portanto, reproduziu as desigualdades de gênero e transmitiu modelos hierárquicos de masculinidades e feminilidades hegemônicas, os quais moldam e naturalizam a posição histórica das mulheres dentro das esferas públicas e privadas. ${ }^{111}$

Estas não foram, no entanto, as únicas reações às manifestações. Como N.P., líder regional do MST no Rio Grande do Sul discute, o evento teve um forte efeito sobre ambos o movimento camponês e a sociedade em geral:

Nós fomos criminalizadas pelo governo, pela mídia e pelo judiciário. Mas isto também gerou um impacto na sociedade. Em primeiro lugar, houve um terror; algumas pessoas ficaram contra, outras a favor. Mas trouxe o tema para a pauta e era isto que a gente queria. Que as pessoas se posicionassem em relação às consequências desse modelo agrícola, baseado na monocultura e na concentração fundiária, e seus efeitos sobre a agricultura camponesa e a reforma agrária. Este evento também produziu muitos resultados dentro do movimento camponês, em particular; a afirmação das mulheres numa perspectiva feminista e classista. Nós já estávamos fazendo isso na luta pela reforma agrária, mas ao lado de nossos companheiros. Mas uma ação desta envergadura surpreendeu os companheiros dos movimentos sociais, não só por causa do tamanho, mas também pelo conteúdo que esta ação gerou. A realização de uma ação desta dimensão revela aos nossos companheiros que nós somos capazes de dirigir a nossa luta.

De modo particular, esta ação reforçou a posição das mulheres dentro do movimento camponês, como atestado pelos líderes masculinos. D. M. afirma que "esta foi uma das ações mais radicais dos últimos anos. E isso foi decidido pelas mulheres do movimento [...]. Com esta ação, elas transcenderam a capacidade masculina de manifestação e força". ${ }^{112}$ J. P. também afirmou que "esta é uma disputa sobre o modelo de agricultura, e as mulheres têm mais perseverança [...]. Hoje em dia, as mulheres estão na linha de frente do movimento. Elas conquistaram este espaço". ${ }^{113}$ Como Emma Siliprandi argumenta, a mobilização política das mulheres rurais tem espantado não só a sociedade em geral e o Estado, mas também os próprios movimentos sociais do campo. $^{114}$

A ocupação da Aracruz tornou-se, portanto "um símbolo da luta de classes com uma perspectiva de gênero; uma demonstração de organização das mulheres, de disciplina, de solidariedade e de resistência". ${ }^{115}$ As próprias mulheres reconhecem esta mudança. Como uma líder local explicitou: “Agora nós sabemos que podemos liderar a 
luta social, porque estávamos habituadas a esperar que os homens assumam a iniciativa". ${ }^{116}$ Isto nem sempre tem sido fácil. A oposição, particularmente o confronto com a polícia em eventos subsequentes, significou que "muitas mulheres ficaram com medo ou perderam o apoio da família por causa de sua participação". ${ }^{117}$ Ao mesmo tempo, "esta ação tem criado uma forte solidariedade entre as mulheres". ${ }^{118}$ L. M. acrescenta: "algumas mulheres estão em um processo mais avançado, mas para outras, que estão mais isoladas nos assentamentos, é mais difícil que seus maridos permitam a sua participação. E é difícil elevar a consciência sem compartilhar experiências com outras mulheres".

Como esta citação sugere, as mudanças no sistema de relações de gênero no contexto da luta pela terra e da organização das mulheres camponesas não são uniformes nem contínuas. ${ }^{119}$ Mesmo quando as mulheres camponesas agem na esfera pública, elas ainda estão segregadas em posições desiguais e/ou pressionadas pelo fardo de seus papéis domésticos, sendo que aquelas em posição de liderança são afetadas de forma distinta das outras participantes. Walby comenta sobre essa diferença:

As mulheres que adaptaram suas vidas a um sistema de patriarcado privado, um regime de gênero doméstico têm um conjunto diferenciado de recursos e vulnerabilidades se comparadas com aquelas que cresceram nas novas formas de um patriarcado mais público, um regime de gênero mais público. Elas terão diferentes valores e moralidades, diferentes agendas políticas e prioridades. ${ }^{120}$

Nem as mudanças são completas. Sob os "regimes patriarcais de gênero", as mulheres camponesas continuam a lutar pelo reconhecimento de que elas são capazes de liderar os movimentos sociais e gerenciar a produção agrícola. ${ }^{121}$ Elas ainda estão lutando pela igualdade de oportunidades para desenvolver seus conhecimentos e suas experiências e para tomar suas próprias decisões. Elas estão resistindo contra um sistema social em que o campesinato tem sido desempoderado e destituído em relação aos recursos naturais e ao acesso ao conhecimento e às tecnologias. Ainda, há evidências de que as mulheres camponesas estão tendo êxito na criação de alternativas ao modelo hegemônico da agricultura e da domesticidade feminina: Através de suas manifestações, elas estão saindo "do ocultamento e do silenciamento da história". ${ }^{122}$ A posição das mulheres de liderar as manifestações no decorrer dos anos constitui um ponto de virada que fornece novas pistas para a compreensão do feminismo na América 
Latina e no mundo, bem como para as interpretações da luta de classes. Mulheres de um grupo social marginalizado estão desafiando o capitalismo internacional e o modelo patriarcal de sociedade. Elas estão afirmando uma ligação histórica com a Mãe Terra e usam isto para justificar a sua campanha para preservar a biodiversidade do planeta e garantir a emancipação humana.

O Dia Internacional da Mulher tem um papel fundamental neste processo. Para as mulheres camponesas da Via Campesina, as celebrações de 8 de Março trazem a unificação da luta de gênero e de classe, com uma perspectiva feminista e socialista. Isso reafirma as origens revolucionárias desta data. Segundo Nalu Faria, a história do Dia Internacional da Mulher traz a complexa luta pela equidade de gênero dentro dos movimentos de esquerda. Também demonstra as limitações das reivindicações feministas se estas não estiverem relacionadas com as transformações estruturais da sociedade como um todo. ${ }^{123}$ Comentários de I. L., uma líder local do MST do assentamento da Annoni, mostram o quanto as mulheres camponesas associam a luta contra o agronegócio com o significado do 8 de março: “As mulheres não estão lá unicamente para discutir o feminismo, mas para fazer uma luta de classes. Advinda não de grandes debates, mas a partir da prática. Isso envolve a questão do modelo tecnológico da agricultura, baseado no uso de produtos químicos e pesticidas". ${ }^{124}$ As Mulheres da Via Campesina, tanto aquelas de organizações camponesas mistas, como o MST, como aquelas de grupos autônomos de mulheres, consideram que a sua luta não se restringe à equidade de gênero e à conquista dos direitos das mulheres e do seu empoderamento, mas envolve também o desenvolvimento de uma modelo de agricultura camponesa e a transformação mais ampla da sociedade:

O movimento de mulheres camponesas continua a ter um papel crucial na luta pela libertação da mulher e para a transformação da sociedade. É um movimento que demanda a agricultura camponesa e a reforma agrária. Além disso, o movimento tem a responsabilidade de lutar pela igualdade de gênero, pelo reconhecimento do trabalho das mulheres e de sua capacidade, porque a cultura patriarcal continua e é forte no campo. ${ }^{125}$

Se nós mulheres não trouxermos nossas demandas para serem discutidas, ninguém vai fazer isso, mas nós não vinculamos nossa luta só com as nossas demandas. Nós conectamos nossas necessidades com o desenvolvimento de um projeto relacionado à soberania alimentar, como um princípio da luta social, com autonomia política do povo e da produção. Agora, há um debate da campanha contra os 
pesticidas, que é um tema estratégico, conectado à sociedade, mas que afeta particularmente as nossas vidas como mulheres camponesas. A definição de demandas que estão relacionadas com as nossas vidas, a nossa produção agrícola, a nossa condição de trabalhadoras e mulheres é um elemento novo na luta das mulheres. ${ }^{126}$

Através de seu ativismo no movimento camponês, estas mulheres desenvolveram uma nova perspectiva feminista que envolve a luta de base, fundamentada na teoria da libertação e no vínculo entre a igualdade de gênero e a luta de classe. Os vários desafios enfrentados pelo campesinato são fundamentais neste processo, com vistas a atingir a libertação de todas as formas de opressão, subalternização e submissão. ${ }^{127}$ Elas estão lutando por uma revolução socialista e, ao mesmo tempo, feminista. Como Conceição Paludo observa, não há emancipação sob o sistema capitalista, mas "há processos emancipatórios que promovem algumas conquistas, denunciam a injustiça e proclamam possibilidades de inovação nas relações sociais, econômicas, políticas e culturais: a possibilidade da emancipação humana."128

Ativistas articularam abertamente estas propostas dentro do movimento social. N.P., líder regional do MST, afirma "Essa ação na Aracruz Celulose gerou uma qualidade na luta de classe a partir da ação das mulheres, uma qualidade na posição feminista das mulheres. Hoje em dia, nós publicamente adotamos uma posição feminista e classista." ${ }^{129}$ Esta identificação das mulheres camponesas como feministas é um fenômeno novo na América Latina, que emerge em função da ação radical assumida por estas manifestantes. ${ }^{130}$ As mulheres camponesas estão re-significando o feminismo dentro de suas organizações. Esta re-conceptualização, que elas chamam de "feminismo camponês e popular", se origina dos movimentos sociais fortemente ligadas ao campo, mas, ao mesmo tempo, está relacionada à luta de classes e à ação política. ${ }^{131}$ Seu foco central está na luta pela vida, contra o sistema patriarcal e capitalista.

Adicionando esta dimensão antipatriarcal à postura anticapitalista, historicamente assumida pelo movimento camponês é, de acordo com Pamela Caro, novo e subversivo e tem um potencial revolucionário visto que destaca a desigualdade de gênero dentro da ideologia e das organizações de esquerda. ${ }^{132}$ Há um entendimento crescente de que "uma forte consciência das desigualdades de classe não leva a uma preocupação semelhante com a desigualdade entre gêneros". ${ }^{133}$ P. N., líder regional do MST, ressalta que "a ideia de que classe e feminismo são lutas simultâneas é um 
elemento que deve ser considerado em nossa luta". ${ }^{134}$ Da mesma forma, a líder local do MST, I. L. enfatiza que: "se nós quisermos construir uma sociedade diferente, precisamos lutar por esta transformação. Mas a luta de classes por si só não leva à conscientização de gênero. Eu posso ser um revolucionário, sem consciência de gênero, porque é uma questão cultural". ${ }^{135} \mathrm{Ou}$ como outra integrante do MST afirma veementemente: "Quando nós assumimos o slogan que "sem feminismo não há socialismo", não é apenas um lema. É uma concepção política, onde o feminismo é considerado como uma demanda para os movimentos sociais, de emancipação humana, a fim de construir outro mundo possível”. ${ }^{136}$

\section{Conclusões}

Como uma "força dinâmica de um processo de modernização em curso", em vez de desaparecer, os movimentos camponeses recriam-se através de diferentes estratégias políticas e formas de resistência. ${ }^{137}$ A participação das mulheres nesta luta de classes e seu envolvimento no movimento das mulheres em nível local, nacional e transnacional têm nutrido a sua ação política e desafiado a sua compreensão de gênero. Este artigo tem argumentado que através de suas ações radicais, as mulheres camponesas têm trazido não só a atenção do público para a controversa questão da monocultura de eucalipto e seu impacto econômico, cultural e ambiental, mas também criado uma agenda feminista dentro da luta de classes. Também demonstrou a forte posição que elas alcançaram dentro do movimento social camponês, bem como as restrições que lhes são impostas pelo "regime patriarcal de gênero" no campo. ${ }^{138}$

As ações das mulheres camponesas proporcionam novas perspectivas para a análise do feminismo, tanto na América Latina quanto no mundo. Como demostrado aqui, as suas manifestações radicais coletivas desafiam as formas tradicionais de participação e os papéis de gênero, transformando-as em um dos principais proponentes do desenvolvimento de uma agricultura agroecológica e sustentável no Brasil. Através de sua luta contra o agronegócio, elas estão desenvolvendo novas formas de participação política e, fundamentalmente, adicionando uma perspectiva feminista na luta de classes em curso. Com a criação de conexões entre diferentes formas de desigualdade, elas têm assegurado uma forte posição de liderança dentro do movimento 
camponês, atuando como visionárias de um modelo alternativo de agricultura, de sociedade e das relações humanas.

${ }^{1}$ De acordo com Maria Martinez-Torres e Peter M. Rosset, a ascensão da Via Campesina deve ser entendida dentro do processo de transformação do Estado na América Latina e seu papel nas áreas rurais. Os autores afirmam que a origem da Via Campesina como um movimento camponês mundial foi prefigurada na América Latina pelo estabelecimento no início de 1990 de um dos seus precursores diretos, a Coordenadora Latinoamericana de Organizaciones del Campo - CLOC (Coordenação Latino-americana de Organizações do Campo). Maria Helena Martinez-Torres e Petter M. Rosset, "La Via Campesina: Transnationalizing Peasant Struggle and Hope," in Latin American Social Movements in the Twenty-First Century: Resistance, Power, and Democracy, eds. Richard Stahler-Sholk, Harry E. Valden e Glend David Kuenker (Lanham: Rowman and Littlefield, 2008), 309.

${ }^{2}$ Uma das principais razões para o crescimento, consolidação e dinamismo dos movimentos sociais rurais nas últimas três décadas, argumentam Carmen Diana Deere e Frederick S. Royce, é o "ataque sem precedentes nos meios de subsistência do campo desencadeado pela globalização neoliberal", em combinação com o "crescimento substancial em termos de capacidade e de espaço político para a organização camponesa, incluindo a transnacionalidade". Carmen Diana Deere e Frederick S. Royce, "Introduction," in Rural Social Movements in Latin America: Organizing for Sustainable Livelihoods, eds. Carmen Diana Deere e Frederick S. Royce (Gainesville: University Press of Florida, 2009), 5.

${ }^{3}$ Martinez e Rosset, "La Via Campesina", 313.

${ }^{4}$ Rajeev Patel, "Global Fascismo, Revolutionary Humanism and the Ethics of Food Sovereignty," Development 48 (2005): 81

${ }^{5}$ Martinez e Rosset, "La Via Campesina," 314.

6 Jane S. Jaquette, The Women's Movement in Latin America: Participation and Democracy (Boulder: Westview Press, 1994).

${ }^{7}$ Por exemplo, ver Sonia E. Alvarez, Engendering Democracy in Brazil: Women's Movements in Transition Politics (Princeton: Princeton University Press, 1990); Nikki Craske, Woman and Politics in Latin America (New Brunswick: Rutgers, 1999); Susan Franceschet, Women and Politics in Chile (Boulder: Lynne Rienner Publishers, 2005); Jaquette, The Women's Movement; Maxine Molyneux, "Mobilization without Emancipation? Women's Interests, the State, and Revolution in Nicaragua," Feminist Studies 11 (1985): 227-254; Georgina Waylen, Engendering Transitions Women's Mobilization, Institutions, and Gender Outcomes (Oxford: Oxford University Press, 2007).

${ }^{8}$ Carmen Diana Deere and Magdalena León, Empowering Women: Land and Property Rights in Latin America (Pittsburgh: University of Pittsburgh Press, 2001), 9.

${ }^{9}$ Por exemplo, a década da mulher e o Ano Internacional da Mulher, em 1975, desempenharam um papel importante no feminismo brasileiro. Céli Regina Jardim Pinto, Uma história do feminismo no Brasil (São Paulo: Fundação Perseu Abramo, 2003); Cynthia A. Sarti, "O feminismo brasileiro desde os anos 1970: Revisitando uma trajetória," Revista Estudos Feministas 12 (2004): 35-50.

${ }^{10}$ Pinto, Uma história do feminismo no Brasil.

${ }^{11}$ Alvarez, Engendering Democracy.

12 Nalu Faria, "Economia feminista e agenda de luta das mulheres no meio rural," in Estatísticas rurais e a economia feminista: um olhar sobre o trabalho das mulheres, ed. Andrea Butto (Brasília: NEAD, 2009), 11-30.

${ }^{13}$ A pesquisa de campo, desenvolvida em 2011, na região sul do Brasil, integrou a pesquisa para minha tese de $\mathrm{PhD}$, intitulada Women's emancipation through participation in land struggle: Brazil and Chile (A emancipação da mulher através da participação na luta pela terra: Brasil e Chile). Esta pesquisa foi financiada pela Universidade Central de Londres - grant awarded by the Academic Trust Funds committee from the Convocation Trust Appeal Fund for the Central Research Fund, e pelo Queen Mary College. Contou também com o apoio da CAPES através da bolsa de estudos do Programa de Doutorado Pleno no Exterior.

14 Paul Thompson, The Voice of the Past: Oral History Second Edition (Oxford: Oxford University Press, 1988). Ver também: Jacques L. Marre, "História de Vida e Método Biográfico," Cadernos de Sociologia 3 (1991): 89-141; Maria I. P. de Queiróz, Variações sobre a técnica de gravador no registro da informação viva (São Paulo: Queiróz, 1991). Este estudo concorda com a visão de 
Alessandro Portelli de que as "fontes orais não são achadas, mas co-criadas pelo historiador" e que o conteúdo dos recursos orais "depende em grande parte do que o entrevistador coloca em termos de questões, de diálogo e de relacionamento pessoal". Alessandro Portelli, A Dialogical Relationship: An Approach to Oral History, http://www.swaraj.org/shikshantar/expressions_portelli.pdf (acessado em 5 de setembro de 2010), 1; Alessandro Portelli, "What Makes Oral History Different," in The Oral History Reader Second Edition, eds. Robert Perks e Alistair Thomson (New York: Routledge, 2006), 39.

${ }^{15}$ Alvarez, Engendering Democracy.

${ }^{16}$ A redação da nova Constituição Federal (1988) instituiu direitos legais para as mulheres e abriu possibilidades para a aplicação destes direitos. Na verdade, medidas em favor das mulheres camponesas foram introduzidas na Constituição em função de uma forte posição do movimento feminista dentro do Estado, mas a conquista dos direitos das mulheres dependeu na prática da luta do movimento das mulheres camponesas. Ver: Carmen D. Deere and Magdalena, León, Towards a Gendered Analysis of the Brazilian Agrarian Reform. (Occasional paper no. 16, New England Consortium of Latin American Studies. Storrs, University of Connecticut, 1999), 44.

${ }^{17}$ Maria J. Carneiro, "Mulheres no campo: notas sobre sua participação política e a condição social do gênero," Estudos Sociedade e Agricultura 2 (1994): 11-22.

${ }^{18}$ Lynn Stephen, Women and Social Movements in Latin America: Power from Below (Austin: University of Texas Press, 1997), 233.

19 Apesar da participação ativa das mulheres nas tarefas da agricultura, elas eram vistas como "donas de casas" e, como consequência, a elas também era negado o direito de serem membros do sindicato. Tomava-se como pressuposto que apenas um membro da família poderia fazer parte do sindicato, geralmente o homem como chefe da casa. Sonia F. Schwendler, "A participação da mulher na luta pela terra: dilemas e conquistas," in Lutas camponesas contemporâneas: condições, dilemas e conquistas Volume II, eds. B. M. Fernandes, L.S. de Medeiros, ed M. I. Paulilo (São Paulo: UNESP e Brasília: NEAD, 2009), 203-221.

${ }^{20}$ Deere e León, Empowering Women, 44.

${ }^{21}$ Anita Brumer, "Gênero e agricultura: a situação da mulher na agricultura do Rio Grande do Sul,” Estudos Feministas 12 (2004): 221.

${ }^{22}$ Os/as camponeses/as entrevistados/as nesta pesquisa serão citados/as pelas iniciais de seus nomes, a fim de preservar seu anonimato.

${ }^{23}$ A OMR foi oficialmente instituída em 1985. Daiane dos S. Carlos e Isaura I. Conte, "Oito de março de 2006: em defesa da vida, mais um marco na luta das mulheres camponesas," in Mulheres, Resistência e Luta: em defesa da vida, ed. Conceição Paludo (São Leopoldo: Cebi, 2009), 75.

${ }^{24}$ Stephen, Women and Social Movements; Maria Ignes S. Paulilo, "El género y la clase en los movimientos de mujeres agricultoras de Brasil," Agricultura, Sociedad y Desarrollo 3 (2006): 175-196.

${ }^{25}$ A primeira experiência de ocupação de terra, que levou à formação do MST, foi a da fazenda Macali durante o regime militar em 07 de setembro de 1979. 110 famílias participaram desta ocupação de terra. Em sua organização e resistência, as mulheres desempenharam um papel importante, especialmente quando a polícia militar do estado fez uma tentativa de expulsar as famílias.

${ }^{26}$ João Pedro Stédile, "Raízes" in Brava Gente: a trajetória do MST e a luta pela terra no Brasil, $3^{a}$ Edição, eds. João Pedro Stédile e Bernardo Mançano Fernandes (São Paulo: Fundação Perseu Abramo, 2005): 15-29.

27 Linda McDowell, Gender, Identity and Place: Understanding Feminist Geographies (Minnesota: Polity Press, 1999), 214.

${ }^{28}$ Pierre Bourdieu, The Logic of Practice (Stanford: Stanford University Press, 1990).

29 Pierre Bourdieu e Loic J. D. Wacquant, An Invitation to Reflexive Sociology (Chicago: University of Chicago Press, 1992), 133.

30 Molyneux, "Mobilization without Emanicaption?", 232-233.

${ }^{31}$ Sonia F. Schwendler, "Women's Emancipation through Participation in Land Struggle" (Tese de Doutorado, University of London, 2013), 48.

${ }^{32}$ Ver Noelle Maria Paule Lechat. A questão de gênero no Movimento dos Trabalhadores Rurais Sem-Terra: estudo de dois assentamentos no Rio Grande do Sul. (Ijuí, RS: UNIJUÍ, 1996).

${ }^{33}$ Carmen Diana Deere, "Women's Land Rights and Rural Social Movements in the Brazilian Agrarian Reform," Journal of Agrarian Change, 3 (2003): 257-288.

${ }^{34}$ Foi a primeira vez que as mulheres e os homens que eram solteiros puderam ser considerados elegíveis para o cadastro no programa de reforma agrária; isto ficou institucionalizado através da Constituição Federal de 1988. Schwendler, “Women's Emancipation through Participation in Land Struggle”, 135. 
${ }^{35}$ Portaria 981/2003. Como resultado, a participação das mulheres como beneficiárias da reforma agrária aumentou significativamente de uma média de 13 por cento antes de 2003 para uma média de 25,6 por cento entre 2003 e 2006. Andrea Butto e Karla Emmanuela R. Hora, "Mulheres e reforma agrária no Brasil," in Mulheres na reforma agrária: a experiência recente no Brasil, eds. Adriana Zarzar Lopes e Andrea Butto (Brasília: MDA, 2010), 19-38.

${ }^{36}$ Else R. P. Vieira. "Marcos Históricos na Trajetória das Mulheres na Política Brasileira" (palestra proferida no Seminário Mulheres na Política Brasileira no Queen Mary College, University of London, London, UK, 24 de setembro de 2010).

37 Deere e León mostram que várias das líderes femininas do Movimento dos Trabalhadores Rurais Sem Terra participaram da fundação da Articulação Nacional de Mulheres Trabalhadoras Rurais (ANMTR) em 1995 e, em seguida, em 1996, elas organizaram o Coletivo Nacional de Mulheres, visto que elas não estavam suficientemente representadas na direção do MST e eram discriminadas em relação à distribuição de terras. Deere and León, "Towards a Gendered Analysis of the Brazilian Agrarian Reform," 21-22.

${ }^{38}$ Sylvia Walby, Gender Transformation (Routledge: London, 1997).

${ }^{39}$ Leonilde S. de Medeiros, "Assentamentos rurais e gênero: temas de reflexão e pesquisa," in Mulheres na reforma agrária: a experiência recente no Brasil, eds. Adriana Zarzar Lopes e Andrea Butto (Brasília: MDA, 2010), 11-12.

${ }^{40}$ É importante considerar que muitos líderes do movimento social camponês desenvolveram seu conhecimento somente através da experiência prática e da formação organizada pelos movimentos sociais. No entanto, esse padrão está mudando para a nova geração de líderes, que, além desta formação, têm mais acesso à educação formal, incluindo a graduação, promovida ou pelo Estado ou por programas educacionais do governo, organizados por meio de parceria entre as universidades públicas e os movimentos sociais. Este é o caso do Programa Nacional de Educação na Reforma Agrária (PRONERA). Fundado em 1998, este programa foi institucionalizado em 04 de abril de 2010 como política de Estado, a fim de viabilizar aos camponeses o acesso à educação profissional (de nível médio e superior) e abordar a questão do analfabetismo no campo.

41 Anita Brumer e Gabriele dos Anjos, "Relações de gênero em assentamentos: a noção de empoderamento em questão," in Mulheres na reforma agrária: a experiência recente no Brasil, eds. Adriana Zarzar Lopes e Andrea Butto (Brasília: MDA, 2010), 226.

${ }^{42}$ Renata Honório Gonçalves, "Vamos acampar: a luta pela terra e a busca pelo assentamento de novas relações de gênero no MST do Pontal do Paranapanema" (Tese de Doutorado, Universidade Estadual de Campinas, 2005).

${ }^{43}$ Entrevista, J. S., líder regional do MST, Via Campesina, 2011.

${ }^{44}$ Annette A. Desmarais, "The International Women's Commission of La Via Campesina," in The Women, Gender and Development Reader Second Edition, eds. Naline Visvanthan, Lynn Duggan, Laurie Nisonoff e Nan Wiegersma (London: Zed Books, 2011), 408-413.

${ }^{45}$ Gonçalves, "Vamos acampar," 274-275.

${ }^{46}$ Susie Jacobs, Gender and Agrarian Reform (New York: Routledge, 2010), 32.

${ }^{47}$ Entrevista, I. M., Coordenação Nacional do MST, Via Campesina, 2011.

${ }^{48}$ Julien-Francois Gerber, "Conflicts over Industrial Tree Plantations in the South: Who, how and why?” Global Environmental Change 21 (2011): 165-176.

49 James Goodman e Ariel Salleh, “The 'Green Economy': Class Hegemony and CounterHegemony," Globalizations 10 (2013): 414.

${ }^{50}$ Gerber, "Conflicts over Industrial Tree Plantations," 171

${ }^{51}$ Gerber, "Conflicts," 165.

${ }^{52}$ Via Campesina. Rompendo o Silêncio. Documentário (Via Campesina: São Paulo, 2006).

${ }^{53}$ Entrevista, MST, Via Campesina, citado em Rompendo o Silêncio.

${ }^{54}$ Entrevista, MST, Via Campesina, citado em Rompendo o Silêncio.

55 Gerber, "Conflicts," 167.

${ }^{56}$ Luiz Alberto Morelli, “A monocultura do eucalipto e a monopolização do território na metade sul do Rio Grande do Sul” (Tese de Doutorado, Universidade Federal do Rio Grande do Sul, 2011), 12.

${ }^{57}$ Gerber, "Conflicts," 166.

${ }^{58}$ Alacir De'Nadai et al, "Promises of Job and destruction of Work: The case of Aracruz Celulose in Brazil," World Rainforest Movement 2 (2005), 9.

${ }^{59}$ Fibria, www.fibria.com.br/eb/en/institucional/onde.htm, (acessado em 09 de abril de 2012).

${ }^{60}$ Conflitos em torno da indústria de plantação de árvores "representam um novo e notável ponto de convergência entre os movimentos agrários e ambientais". Gerber, "conflitos", 174.

${ }^{61}$ Gerber, 2011. 
${ }^{62}$ Mitschka J. Hartley, "Rationale and Methods for Conserving Biodiversity in Plantation Forests," Forest Ecology and Management 155 (2002): 81-95.

${ }^{63}$ Klítia Loureiro, "A instalação da empresa Aracruz Celulose S/A e a "moderna" ocupação das terras indígenas Tupiniquim e Guarani Mbya,” Revista Ágora 3 (2006): 21.

${ }^{64}$ Via Campesina. Rompendo o Silêncio.

${ }^{65}$ Entrevista, líder indígena, citado em Rompendo o Silêncio.

${ }^{66}$ Em 1996, estudos realizados pela Fundação Nacional do Índio (FUNAI) identificaram 18.000 hectares, na área onde a Aracruz atuava, como sendo terras indígenas. No entanto, 11.009 hectares ainda eram de propriedade da empresa Aracruz Celulose, até 2010, quando a demarcação da terra indígena (18.154 hectares) foi ratificada pelo governo brasileiro (DOU 08/11/2010). CIMI, http://www.cimi.org.br/site/pt-br/?system=news\&action=read\&id=2729\&page=567, (acessado em $9 \mathrm{de}$ abril de 2012); CIMI, http://6ccr.pgr.mpf.mp.br/documentos-e-publicacoes/terras-indigenas/dados-geraispovos-e-terras-indigenas-no-brasil, (acessado em 12 de abril de 2012).

${ }^{67}$ Entrevista, líder indígena, citado em Rompendo o Silêncio.

${ }^{68}$ Via Campesina, Rompendo o Silêncio.

${ }^{69}$ Octavio Ianni, "Revoluções camponesas na America Latina," in Revoluções camponesas na América Latina, ed. José Vicente T. dos Santos (São Paulo: Ícone; Ed da UNICAMP, 1985), 14-45.

${ }^{70}$ José de Souza Martins, Expropriação e violência: a questão política no campo (São Paulo: Hucitec, 1991), 50-52.

${ }^{71}$ Ianni, "Revoluções camponesas na América Latina," 14-45.

${ }^{72}$ Winifred Overbeek, "Brazil: The struggle of the Green Desert Network," Word Rainforest Movement 101 (2005), http://www.wrm.org.uy/oldsite/bulletin/101/Brazil.html, (acessado em 15 de abril de 2012).

${ }^{73}$ Sergio Schneider, "Os colonos da indústria calçadista: a expansão industrial e as transformações da agricultura familiar no Rio Grande do Sul,” Ensaios FEE 17 (1996): 312.

${ }^{74}$ Entrevista, E. S., MST, líder local do Assentamento da Annoni, 2011.

${ }^{75}$ Principal fábrica da Aracruz, localizada em Guaíba, foi comprada em 2003 e vendida em 2009 para uma empresa chilena. Em 2006, a empresa anunciou grandes investimentos para expandir a indústria. (Morelli, 2011).

${ }^{76}$ Luiz Alberto Morelli, “A monocultura do eucalipto," 117-118.

77 Via Campesina, O latifúndio dos Eucaliptos: informações básicas sobre as monoculturas de árvores e as indústrias de papel (Rio Grande do Sul: Via Campesina, 2006).

${ }^{78}$ Via Campesina, O latifúndio dos Eucaliptos, 13.

${ }^{79}$ Luiza Chomenko, "Um panorama sobre o cultivo de monocultura de árvores," Cadernos IHU em formação. A monocultura do eucalipto: deserto disfarçado de verde? 4 (2008): 38.

${ }^{80}$ Chomenko, "Um panorama sobre," 31, 37.

${ }^{81}$ De'Nadai et al., 2005.

${ }^{82}$ Chomenko, “Um panorama sobre," p. 32.

${ }^{83}$ Entrevista, E.S., MST, líder local do Assentamento da Annoni, 2011.

${ }^{84}$ Miqueline Isabel L. De Faveri, "Desertos verdes: análise documental da cobertura dos jornais Correio do Povo e Zero Hora, de 9 a 18 de março de 2006, sobre a expansão da monocultura de eucaliptos no Rio Grande do Sul," (Monografia, Universidade Federal do Rio Grande do Sul, 2007), 27.

${ }^{85}$ Leonardo Melgarejo, "Agricultura x monocultura: o empobrecimento do bioma," Cadernos IHU em formação. A monocultura do eucalipto: deserto disfarçado de verde? 4 (2008): 52.

${ }^{86}$ Morelli, “A monocultura do eucalipto," p. 6.

87 Bernardo Mançano Fernandes, "Occupation as a Form of Access to Land," University of Nottingham, http://www.landless-voices.org, (acessado em 15 de novembro de 2011); Bernardo Mançano Fernandes, "Questão agrária: conflitualidade e desenvolvimento territorial," in Luta pela terra, reforma agrária e gestão de conflitos no Brasil, eds. Antonio Marcio Buainain et al. (Campinas: UNICAMP, 2008), 173-230.

${ }^{88}$ Gerber, "Conflicts over Industrial Tree Plantations," p. 173.

${ }^{89}$ Gerber, "Conflicts over Industrial Tree Plantations," p. 173.

90 Annete A. Desmarais, "The Via Campesina: Peasant Women on the Frontiers of Food Sovereignty." Canadian Woman Studies/les cahiers de la femme 23 (2003): 142.

91 Elisabete Witzel e Maria A. Silveira, "Mulheres da Via Campesina," Cadernos IHU em formação. A monocultura do eucalipto: deserto disfarçado de verde? 4 (2008): 86.

${ }^{92}$ Faria, "Economia feminista," p. 24.

93 Martinez e Rosset, “La Via Campesina,” p. 313. 
${ }^{94}$ Martinez e Rosset, “La Via Campesina,” p. 314. Para maiores discussões sobre o modelo de soberania alimentar, ver também: Patel, "Global Fascismo," 81; Hen Bernstein, "A dinâmica de classe do desenvolvimento agrário na era da globalização," Sociologias 13 (2011): 52-81; Horácio Martins Carvalho, $\mathrm{Na}$ sombra da imaginação: reflexão a favor dos camponeses. http://www2.fct.unesp.br/nera/artigodomes/5artigodomes_2010.pdf, (acessado em 15 de março de 2012).

95 Desmarais, "The Via Campesina," p. 143.

${ }^{96}$ Entrevista, S. K, líder nacional do MMC, Via Campesina, 2011.

${ }^{97}$ Desmarais, "The Via Campesina," p. 143. Ver também: Sofia Monsalve, "Gender and Land," in Promised Land: Competing Visions of Agrarian Reform, eds. Peter Rosset, Rajeev Patel, e Michael Courville (Oakland: Food First Books, 2005), 192-207.

${ }^{98}$ Entrevista, E. F, líder local MST, Via Campesina, 2011.

99 Via Campesina. Greetings from La Via Campesina to the Women of the World, www.viacampesina.org, (acessado em 11 de novembro de 2011).

${ }^{100}$ Entrevista, J. S. , líder regional do MST, a Via Campesina, 2011.

101 Antônio Canuto, "Os movimentos sociais em ação no campo," in Conflitos no campo Brasil 2009, eds. Antônio Canuto, Cassia R. Da Silva Luz e Isolete Wichinieski (São Paulo: Expressão Popular, 2010), 142-147.

${ }^{102}$ Cristina Zanella Rodrigues. "As mudas romperam o silêncio": discurso ecológico e movimento campesino. (Dissertação de Mestrado, Universidade Católica de Pelotas, 2009), 38-41.

${ }^{103}$ De Faveri, "Desertos verdes," 64-65.

104 Maíra Kubík T. Mano, "Deserto verde, imprensa marrom: o protagonismo político das mulheres nas páginas dos jornais” (Dissertação de Mestrado, Pontifícia Universidade Católica de São Paulo, 2010), 36.

105 Rodrigues, "As mudas romperam o silêncio", 38-39.

106 Correio do Povo, "Vandalismo prejudica décadas de pesquisa," (Porto Alegre, Correio do Povo, 9 de março de 2006). http://www.correiodopovo.com.br/Jornal/A111/N160/HTML/ (acessado em 12 de abril de 2012); Folha de São Paulo, "Mulheres depredam fábrica de celulose no RS," (São Paulo, Folha de São Paulo, 8 de março 2006). http://www1.folha.uol.com.br/folha/brasil/ult96u76373.shtml, (acessado em 12 de abril de 2012).

${ }^{107}$ Rodrigues, "As mudas romperam o silêncio," 41.

${ }^{108}$ Entrevista, J. S., líder regional do MST, Via Campesina, 2011.

${ }^{109}$ Via Campesina, O latifúndio dos Eucaliptos, p. 27.

${ }^{110}$ Carlos e Conte, "Oito de março de 2006," p. 157.

${ }^{111}$ Mano, "Deserto verde," 57.

${ }^{112}$ Entrevista, D. M., líder local do MST, 2011.

${ }^{113}$ Entrevista, J. P., ex-líder nacional do MST, 2011.

${ }^{114}$ Emma Siliprandi, "Mulheres agricultoras e a construção dos movimentos agroecológicos no Brasil," in Mulheres camponesas: trabalho produtivo e engajamentos políticos, eds. Delma P. Neves e Leonilde S. De Medeiros, (Niterói: Alternativa, 2013), 336.

${ }^{115}$ Carlos e Conte, "Oito de março de 2006," 158.

${ }^{116}$ Entrevista, E. F., líder local do MST, 2011.

${ }^{117}$ Entrevista, L. V., Assentamento da Annoni, 2011.

${ }^{118}$ Entrevista, I. L, MST, líder local do Assentamento da Annoni, 2011.

${ }^{119}$ Sonia F. Schwendler, "The Construction of the Feminine in the Struggle for Land and in the Social Re-creation of the Settlement," University of Nottingham, http://www.landless-voices.org, (15 de abril de 2012).

${ }^{120}$ Walby, Gender Transformations, 11.

121 Jacobs, Gender and Agrarian Reform, 2010.

${ }^{122}$ Isaura Isabel Conte, "Retalhos de História das mulheres camponesas," Revista Semina 8 (2009):

11.

${ }^{123}$ Faria, Nalu (prefácio). In As origens e a comemoração do Dia Internacional das Mulheres, por Ana Isabel Álvarez González; traduzido por Alessandra Ceregatti et al. (São Paulo: Expressão Popular; SOF - Sempre viva Organização Feminina, 2010), 9-19.

${ }^{124}$ Entrevista, I. L., MST, líder local do Assentamento da Annoni, 2011.

${ }^{125}$ Entrevista, J. C., membro fundador do Movimento de Mulheres Camponesas, Via Campesina, 2011.

${ }^{126}$ Entrevista I. M., membro da Coordenação Nacional do MST, Via Campesina, 2011.

${ }^{127}$ Schwendler, "Women's Emancipation," 51. 
${ }^{128}$ Conceição Paludo, Mulheres, Resistência e Luta: em defesa da vida (São Leopoldo: Cebi, 2009), 11

${ }^{129}$ Entrevista, N. P., líder regional do MST, Via Campesina, 2011.

${ }^{130}$ Sônia F. Schwendler, “Without Feminism there is no Socialism': Discourses and Subversive Practices in Latin America," International Journal of Diversity in Organizations, Communities and Nations, 11 (2012), 131.

${ }^{131}$ Schwendler, "Without Feminism," 132.

132 Pamela Caro, "La transgresión del feminismo campesino y popular: Autonomías y soberanías," Autonomía política de las mujeres: algunas reflexiones, ed. Centro Regional de Derechos Humanos y Justicia de Género (Santiago de Chile: Regional de Derechos Humanos y Justicia de Género, 2011), 117 142.

133 Paulilo, "El género," 188.

${ }^{134}$ Entrevista, N. P., líder regional do MST, Via Campesina, 2011.

${ }^{135}$ Entrevista, I. L., MST, líder local do Assentamento da Annoni, 2011.

${ }^{136}$ I. M., membro da Direção Nacional do MST, Via Campesina, entrevista, 2011. Este slogan foi cunhado durante a IV Assembleia da Articulação de Mulheres Camponesas da Coordenadora Latinoamericana de Organizações do Campo (CLOC) - Via Campesina, realizada em Quito, Equador, em outubro de 2010.

${ }^{137}$ James Petras e Henry Veltmeyer. "Are Latin American Peasant Movements Still a Force for Change? Some New Paradigms Revisited." The Journal of Peasant Studies. 28: 2 (2001), 92; Deborah Bryceson, Cristóbal Kay, Jos Mooij, eds. "Disappearing Peasantries? Rural Labour in Africa, Asia and Latin America," (London: Intermediate Technology Publications, 2000); Fernandes, "Questão agrária: conflitualidade e desenvolvimento territorial," 173-230; Sérgio Gómez. "Organización campesina en Chile: reflexiones sobre su debilidad actual.” In: Revista Austral de Ciencias Sociales, 6 (2002): 3-18.

${ }^{138}$ Jacobs, Gender and Agrarian Reform, 2010. 